\title{
Exosomes: mediators of communication in eukaryotes
}

\author{
María A. Lopez-Verrilli ${ }^{1 *}$ and Felipe A. Court ${ }^{1,2 *}$ \\ ' Millennium Nucleus for Regenerative Biology, P. Catholic University of Chile, Santiago, Chile \\ ${ }^{2}$ NeuroUnion Biomedical Foundation, Santiago, Chile
}

\begin{abstract}
In addition to the established mechanisms of intercellular signaling, a new way of communication has gained much attention in the last decade: communication mediated by exosomes. Exosomes are nanovesicles (with a diameter of 40-120 nm) secreted into the extracellular space by the multivesicular endosome after its outer membrane fuses with the plasma membrane. Once released, exosomes modulate the response of the recipient cells that recognize them. This indicates that exosomes operate in a specific manner and participate in the regulation of the target cell. Remarkably, exosomes occur from unicellular organisms to mammals, suggesting an evolutionarily conserved mechanism of communication. In this review we describe the cascade of exosome formation, intracellular traffic, secretion, and internalization by recipient cells, and review their most relevant effects. We also highlight important steps that are still poorly understood.
\end{abstract}

Key words: Exosome, nanovesicle, intercellular communication.

\section{INTRODUCTION}

Cell-cell communication is imperative for life. There are different pathways of intercellular communication, such as the expression of signalling molecules on plasma membranes or the secretion of soluble ligands (Grimmelikhuijzen and Hauser, 2012), gap junctions and tunneling nanotubes that allow electrical and metabolic coupling among cells (Abounit and Zurzolo, 2012; Orellana et al., 2012). In addition to these modes of communication, cells release membrane vesicles into the extracellular environment that affect target cells (Simons and Raposo, 2009).

In the 1980s, the groups of Stahl and Johnstone described the secretion of nano-sized vesicles during reticulocyte maturation (Harding et al., 1983; Pan et al., 1985). These vesicles were named exosomes and were thought to be necessary to remove unneeded proteins from cells (Johnstone et al., 1987). Later, Raposo et al. described that exosomes had antigen-presenting capacity (Raposo et al., 1996). Thereafter, the study of functional effects of exosomes has grown steadily (Simons and Raposo, 2009; Thery et al., 2009; Record et al., 2011; Pant et al., 2012).

Exosome release has been shown in eukaryotes, from microorganisms up to mammals. For example, they are secreted by protists like Dictyostelium discoideum (Lavialle et al., 2009) and Trypanosoma cruzi (Bayer-Santos et al., 2012), fungi (Rodrigues et al., 2011), plants (Regente et al., 2012), and animals from invertebrates such as Drosophila melanogaster (Korkut et al., 2009; Beckett et al., 2012; Gross et al., 2012) and Caenorhabditis elegans (Liegeois et al., 2006) to vertebrates (Record et al., 2011).

As depicted in figure 1, four sequential steps have been described in the literature for exosome-mediated communication. To date, this cascade comprising exosome formation, intracellular traffic, secretion and internalization by recipient cells, has been best characterized in immune cells (Thery et al., 2009; Bobrie et al., 2011) while the information in other cell types is fragmented. Considering this, we propose that communication mediated by exosomes between cells must have been conserved throughout evolution, although how this pathway may have evolved is not yet known. In this review we aim to illustrate the current state of knowledge of this particular way of cellular communication.

\section{EXOSOME-MEDIATED COMMUNICATION}

\section{Exosome biogenesis}

Multivesicular endosomes (MVE, also called multivesicular bodies or MVB) give rise to exosomes as follows. The membrane of late endosomes invaginates and forms small vesicles that are pinched off into the endosomal space. These are the intralumenal vesicles (ILV) and the whole is the MVE (Fig. 1A). Notice that the internal face of an ILV membrane corresponds to the cytoplasmic face of the endosome limiting membrane, and the content of the ILV is originated from the cytosol prior to ILV formation. This anatomical fact has functional relevance for exosomes. A set of MVEs fuse their limiting membranes to the plasma membrane and the ILVs with their cargo into the extracellular space. These secreted vesicles are exosomes (Fig. 1B-C) (Simons and Raposo, 2009).

Formation of ILVs in the late endosome involves the endosomal sorting complex required for transport (ESCRT) proteins (Babst, 2011). ESCRT proteins are components of four ESCRT complexes, ESCRT-0, ESCRT-I, ESCRT-II, and ESCRT-III (Hanson et al., 2009). Each of these complexes is sequentially and transiently recruited to the forming MVE until a vesicle is fully shaped and released as an ILV into the endosomal space (Hurley and Emr, 2006). However, increasing evidence suggests that some lipids such as ceramide may play a key role in ILV formation, independently of ESCRT complexes (Trajkovic et al., 2008; Babst, 2011).

As mentioned above, a set of MVE fuse with the plasma membrane while other MVEs follow a degradative route and

\footnotetext{
* Corresponding authors: María A. Lopez-Verrilli and Felipe A. Court, Department of Physiology, Faculty of Biology, Pontificia Universidad Católica de Chile, Av. B. O’Higgins 340/Casilla 114-D, Santiago 8331150, Chile. Phone: (00562) 686 2899, Fax: (00562) 354 1850, e-mail: alejanddra@gmail.com; fcourt@bio.puc.cl
} 
fuse with lysosomes. This pathway leads to the degradation of ILVs content. Which are the mechanisms that guide MVE fusion with the plasma membrane or with lysosomes? Evidence to date is incomplete but supports the existence of different populations of MVEs (White et al., 2006) and/or different subpopulations of ILVs within a pool of common MVEs. Accordingly, MVEs rich in Rab7 GTPase and ILVs containing phosphatidylinositol-3-phosphate and ubiquitinated proteins are sorted to lysosomes (Vanlandingham and Ceresa, 2009). Conversely, MVEs rich in Rab11 GTPase and ILVs with high amounts of ceramide are sorted for exosome secretion (Zerial and McBride, 2001; Savina et al., 2005). Rab GTPases coordinate intracellular traffic, such as vesicle formation, transport and fusion with the target membranes (Zerial and McBride, 2001). In this way, the recruitment of specific Rabs and their effectors to MVEs membrane directs their final destination towards degradation or exosome secretion.

\section{Loading of exosomes}

In eukaryotes, most secreted proteins use the endoplasmic reticulum/Golgi-dependent secretory pathway (Keller and Simons, 1997). These proteins have a signal peptide which directs their fate towards the exocytic route (Nickel, 2005). However, proteins that follow unconventional secretory pathways, such as the exosome-mediated route, do not use this signal peptide. What commands the secretion of cellular components within vesicles and how are molecules sorted into exosomes? Ubiquitination is the best characterized signal that commands protein sorting into ILVs, for both cytosolic proteins and the cytosolic tail of membrane receptors (Baietti et al., 2012). Ubiquitinated-proteins interact sequentially with the ESCRT complex and with specific domains of late endosomes. This leads to the invagination of the late endosome membrane together with the tagged-protein and the final formation of an ILV (Babst, 2011; MacDonald et al., 2012). However, some non-ubiquitinated proteins such as the transferrin receptor interact with the ESCRT complex and are sorted into exosomes, suggesting that different protein interactions can provide access to ESCRT processing (Marsh and van Meer, 2008). In fact, an alternative mechanism to ubiquitin-tagging has been recently described for a plasma membrane receptor (Baietti et al., 2012). Syndecans -transmembrane proteins that offer heparin sulphate to the cell surface- recruit the fibroblast growth factor receptor into MVEs. To achieve this, the cytosolic domain of syndecan interacts with the adaptor protein syntenin which in turn connects syndecans to Alix, an auxiliary component of the ESCRT machinery. This syndecan-syntenin-Alix pathway leads to the exosome secretion of fibroblast growth factor receptor (Baietti et al., 2012). It remains to be explored whether this new pathway is sufficient to recruit other plasma receptors, such as the transferrin receptor, into exosomes.

Finally, tetraspanins -evolutionarily conserved transmembrane proteins- have been proposed to mediate molecule sorting into ILVs (Rana and Zoller, 2011). Tetraspanins form microdomains in the cell surface by interacting between themselves and a large variety of transmembrane and cytosolic proteins and participate in

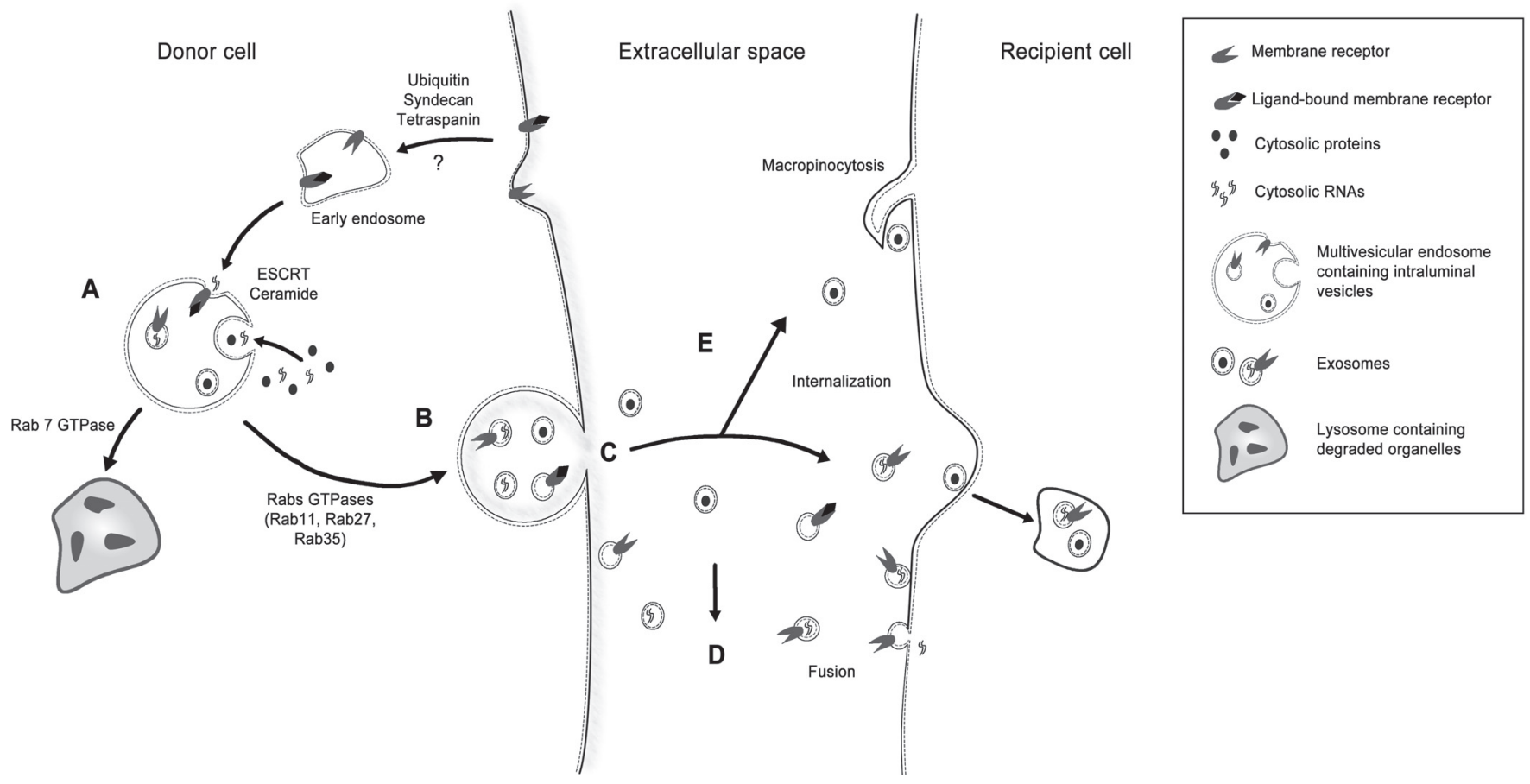

Figure 1. Sequential steps necessary for exosome-mediated communication. Intralumenal vesicles (ILV) are formed after the invagination of the multivesicular endosome membrane. These ILVs are loaded with specific cargo originated from the plasma membrane and/ or the cytoplasm (A). Notice that the internal face of an ILV membrane corresponds to the cytoplasmic face of the endosome limiting membrane, and the ILV is loaded with cytosolic components. Upon fusion of the MVE with the plasma membrane (B), ILV are secreted as exosomes (C). Exosomes can be lost (D) or taken up by target cells (E) by fusion, or internalization mediated by surface molecules or by macropinocytosis. Additional abbreviation: ESCRT, endosomal sorting complex required for transport. 
vesicular traffic (Levy and Shoham, 2005). Although this field is quite speculative to date, exosomes from all cell types are enriched in tetraspanins, thus they are plausible candidates to mediate selective cargo recruitment into these vesicles.

The sorting process of protein complexes into ILVs is a highly regulated mechanism. Most proteins secreted by exosomes derive from parent cell membranes, the cytosol or the Golgi, but rarely the endoplasmic reticulum or mitochondria. Some of the proteins sorted into ILV participate in antigen presentation (MHC-I, MHC-II), cell adhesion (integrins), cell structure and motility (actins, tubulin, myosin, etc.), stress regulators (heat shock proteins 70 and 90), metabolic enzymes (b-enolase, peroxidases, pyruvate kinase) proteins of ESCRT machinery, proteins of the signalling cascade (kinases), tetraspanins (CD9, CD63, CD81, CD82), proteins involved in transcription and protein synthesis (histones, ribosomal proteins, ubiquitin), and proteins involved in trafficking and membrane fusion (Rabs, annexins) (Lakkaraju and RodriguezBoulan, 2008). Additionally, cytosolic proteins remain in the lumen of exosomes and those derived from the plasma membrane remain in the vesicle membrane, maintaining the same topology they had in the cell, with potential roles in sequestering soluble ligands (Pan et al., 1985; Thery et al., 2009).

Although exosomes were originally described in 1980's, interest in these vesicles was renewed in recent years when exosomes were reported to contain functional mRNA and microRNA (Valadi et al., 2007). The functional consequences of transfer of genetic material include the induction, amplification and/or modulation of immune responses, as well as acquisition of new functional properties in other recipient cells. For example, glioblastoma cells carrying EGFRvIII mRNA have been shown to stimulate tubule formation in endothelial cells and proliferation of glioblastoma cells, thereby promoting acquisition of the angiogenic phenotype and metastatic abilities (Skog et al., 2008). Exosomes have been shown to be highly enriched in defined mRNA species compared to their distributions in the donor cell (Skog et al., 2008). This fact supports the existence of a sorting mechanism, but it has not been characterized so far.

Exosomes contain not only proteins and nucleic acids but also a specific lipid composition; they are rich in cholesterol, sphingomyelin and ceramide; and they also exhibit phosphatidylserine (Thery et al., 2009). Interestingly, bioactive lipids such as prostaglandins are also sorted into exosomes (Subra et al., 2010). ExoCarta -a free to use web-database of proteins, RNA and lipids identified in exosomes- has been compiled and reveals molecules that are more often found in exosomes and those that are specific to certain cell types (http:// www.exocarta.org) (Mathivanan and Simpson, 2009).

In conclusion, the effort to characterize the composition of exosomes has been largely successful but the data on a mechanism to recruit the cargo have been meager. This shows a clear need to characterize the interactions between proteins, lipids and RNAs that allow specific cargo packaging into exosomes.

\section{Secretion of exosomes}

The secretion of exosomes has been described both in vivo and in vitro as a non-conventional secretory mechanism (Nickel, 2005). As mentioned above, once the MVEs fuse with the plasma membrane, ILVs are secreted as exosomes (Fig. 1C). Electron microscopy analysis of exosomes show a cup-shaped morphology and a size between 40-120 nm (Simons and Raposo, 2009). Exosomes have been isolated in vitro but also in vivo in bodily fluids such as blood, urine, breast milk, amniotic fluid, malignant ascites, bronchoalveolar lavage fluid and synovial fluid (Record et al., 2011).

Exosomes are released both constitutively and in a regulated manner. For example, B cells secrete detectable levels of exosomes only following the activation of a cell surface receptor (Saunderson et al., 2008) while most tumor cells constitutively secrete exosomes (Record et al., 2011). Importantly, distinct subpopulations of exosomes are secreted from polarized cells; apical and basolateral exosomes (Tauro et al., 2012). This indicates that exosome secretion can be even more complex, since a different mechanism may coexist in the cell to target exosome release to the appropriate membrane.

Intracellular calcium is a physiological second messenger in the secretion of exosomes (Savina et al., 2003; Faure et al., 2006). In murine macrophages, dendritic and neuroblastoma cells, activation of $\mathrm{P} 2 \mathrm{X}_{7}$ receptors (purinergic receptor $\mathrm{P} 2 \mathrm{X}$ ) by ATP increases intracellular calcium and also secretion of exosomes (Qu et al., 2009; Emmanouilidou et al., 2010). Pharmacological elevation of intracellular calcium also induces exosome secretion in cortical neurons, oligodendrocytes and erythroleukemia cells (Savina et al., 2003; Faure et al., 2006; Fruhbeis et al., 2012), which confirms the role of calcium as second order messenger. Together with a cytosolic calcium increase, the expression of Rab11 GTPase is needed for exosome secretion in erythroleukemia cells in vitro (Savina et al., 2005). In fact, calcium dependent-exosome secretion is enhanced when cells with low endogenous levels of the Rab11 are manipulated to overexpress this GTPase (Savina et al., 2005). Although the direct link between calcium and Rabs is missing, two other Rab proteins have been implicated in the fusion of MVE membrane to the plasma membrane of mammalian cells. For example, Rab35 is involved in the secretion of myelin protein-enriched exosomes in oligodendroglial cells and Rab27a/b but not Rab11 mediates MVE transport and docking to the plasma membrane in HeLa cells in vitro (Hsu et al., 2010; Ostrowski et al., 2010). Finally, in the motor nerve endings of the fly $D$. melanogaster exosome secretion is regulated by Rab11 but not by Rab27 or Rab35, while secretion of vesicles loaded with neurotransmitter required Rab3, which suggests a specific pathway for exosomes (Koles et al., 2012). These results reflect the variety of secretory pathways during exosome formation within a cell and in diverse cell types (Koles et al., 2012). Collectively, calcium and specific Rab GTPases participate in the fusion of MVEs to the plasma membrane as a step in the secretion of exosomes. Taken together, this evidence indicates that exosome secretion, besides being constitutive, is also regulated.

Eukaryotic cells have developed elaborate mechanisms of quality control within their classical ER/Golgi-dependent secretory pathway. It is likely that a quality control is also operating in the exosome pathway. However, the molecular machinery involved in the transport of MVEs to the plasma membrane, their docking and fusion to release exosomes is poorly understood.

\section{Exosome uptake by recipient cells}

Once in the extracellular space, exosomes may be eliminated (Fig. 1D). This fate is illustrated by their presence in urine 
(Miranda et al., 2010). The biological significance of this elimination, if any, has not been explored. By contrast, exosomes have important effects on target cells (Fig. 1E). Interaction of exosomes with target cells follows two alternatives; endocytosis of the whole vesicle or and/or fusion with the plasma membrane. Membrane vesicles of all cellular origins express adhesion molecules on their surface, which could favor their endocytosis by recipient cells (Record et al., 2011). For example, surface molecules such as integrins, tetraspanins and phosphatidylserine in exosomes form complexes with cell surface molecules and participate in the attachment of exosomes, as studied in dendritic cells (Thery et al., 2009). In these cells, the whole exosome is internalized and sorted into recycling endosomes and then through late endosomes/lysosomes (Morelli et al., 2004). Co-incubation of exosomes and dendritic cells with specific antibodies to block various adhesion molecules reduces exosome internalization by these cells (Morelli et al., 2004). By this mechanism, dendritic cells process and then present to $\mathrm{T}$ lymphocytes peptides derived from the internalized exosomes. Alternatively, exosomes can be selectively internalized by macropinocytosis, a mechanism where macromolecules are taken by actinmembrane ruffles, and that does not necessarily depend on receptor-ligand interaction (Fitzner et al., 2011). On the other hand, fusion of exosomes has been shown to be a lipiddependent process, in which a high content of sphingomyelin/ ganglioside GM3 in exosomes is responsible for the increased fusion efficiency in tumor cells (Parolini et al., 2009), while

\section{TABLE}

Representative findings of functional effects of exosomes in eukaryotes

\begin{tabular}{|c|c|c|c|}
\hline Organism & Exosome source & Effect & References \\
\hline \multirow[t]{2}{*}{ Protists } & $\begin{array}{l}\text { Dictyostelium } \\
\text { discoideum }\end{array}$ & $\begin{array}{l}\text { Exosomes-like vesicles are secreted by D. } \\
\text { discoideum migrating cells and coordinate cell } \\
\text { migration. These vesicles have been proposed } \\
\text { for drug carriers in cancer therapy. }\end{array}$ & (Kriebel et al. 2008; Lavialle et al. 2009) \\
\hline & $\begin{array}{l}\text { Leishmania } \\
\text { donovani, } \\
\text { Trypanosoma cruzi }\end{array}$ & $\begin{array}{l}\text { Exosomes deliver parasite cargo into host cells } \\
\text { and modulate the immune response. }\end{array}$ & (Silverman et al. 2010; Bayer-Santos et al. 2012) \\
\hline Fungi & $\begin{array}{l}\text { Histoplasma } \\
\text { capsulatum, } \\
\text { Cryptococcus } \\
\text { neoformans }\end{array}$ & $\begin{array}{l}\text { Fungal species secrete extracellular vesicles with } \\
\text { similar composition to exosomes. These vesicles } \\
\text { are involved in host-pathogen interactions. }\end{array}$ & (Albuquerque et al. 2008; Rodrigues et al. 2008) \\
\hline Plants & $\begin{array}{l}\text { Sunflower seeds, } \\
\text { barley leaves }\end{array}$ & $\begin{array}{l}\text { Isolation and characterization of exosomes from } \\
\text { seed and leaved fluids. }\end{array}$ & (An et al. 2007; Regente et al. 2009) \\
\hline \multirow[t]{16}{*}{ Animals } & $\begin{array}{l}\text { Caenorhabditis } \\
\text { elegans }\end{array}$ & $\begin{array}{l}\text { Polarized secretion of morphogens mediated by } \\
\text { exosomes. }\end{array}$ & (Liegeois et al. 2006) \\
\hline & $\begin{array}{l}\text { Drosophila } \\
\text { melanogaster }\end{array}$ & Wnt morphogens secretion during development. & (Korkut et al. 2009; Beckett et al. 2012; Gross et al. 2012) \\
\hline & Mammalian cells & Antigen presenting capacity & First functional effect: (Raposo et al. 1996) \\
\hline & & & Others: (Mittelbrunn et al. 2011; Huan et al. 2012) \\
\hline & & $\begin{array}{l}\text { Exosomes contain mRNA and microRNA that } \\
\text { can be transferred }\end{array}$ & First antecedent: (Valadi et al. 2007) \\
\hline & & to other cells where they are functional. & Others: (Lasser et al. 2011; Gallo et al. 2012) \\
\hline & & "Trojan horses" for pathogens propagation: & \\
\hline & & - Prions & - (Fevrier et al. 2004; Vella et al. 2008) \\
\hline & & - Virus & - (Barreto et al. 2010; Lenassi et al. 2010) \\
\hline & & - Bacteria & - (Yang et al. 2012) \\
\hline & & Spread of neurodegenerative diseases. & (Emmanouilidou et al. 2010; Saman et al. 2012) \\
\hline & & Antitumoral effects. & (Zhang et al. 2011; Lv et al. 2012) \\
\hline & & Pro-angiogenic, pro-metastasic. & (Al-Nedawi et al. 2008; Peinado et al. 2012) \\
\hline & & Biomarkers for cancer diagnosis and prognosis. & (Skog et al. 2008; Miranda et al. 2010; Khan et al. 2012) \\
\hline & & Future therapy models. & (Alvarez-Erviti et al. 2011; Zhuang et al. 2011) \\
\hline & & $\begin{array}{l}\text { Tolerogenic pre-transplantation and anti-cancer } \\
\text { vaccines }\end{array}$ & $\begin{array}{l}\text { (Hartman et al. 2011; Rountree et al. 2011; Viaud et al. } \\
\text { 2011; Li et al. 2012) }\end{array}$ \\
\hline
\end{tabular}


cholesterol-rich microdomains are necessary for dendritic cell exosome fusion with target cells (Montecalvo et al., 2012).

In any case, an important unanswered question in the field is how exosomes deliver their intralumenal content into the cytosol of the recipient cells.

\section{Effect of exosome cargo on recipient cells}

Since the discovery that exosomes participate in the cascade of antigen presentation (Raposo et al., 1996), this novel mechanism of intercellular communication has been implicated in various essential processes such as development (Korkut et al., 2009), immune responses (Thery et al., 2009), cancer and tumor metastasis (Peinado et al., 2012), and in the transmission of infectious agents like prions and viruses (Fevrier et al., 2004; Lenassi et al., 2010). Table I provides an overview of the most relevant findings of exosome functional effects in eukaryotes to date. It is worth mentioning that studies on exosomes other than mammalian cells are scant but still support the role of exosomes as a conserved mechanism of communication throughout evolution.

Finally, exosomes are promising tools to target drugs or biological material to specific cells across different biological barriers (O'Loughlin et al., 2012; Pant et al., 2012). For example, Alvarez-Erviti et al. (2011) obtained neuronal-targeted exosomes from genetically modified dendritic cells in vitro and loaded them with specific siRNA. After intravenous injection, these exosomes loaded with siRNA knocked down their target gene in brain neurons (Alvarez-Erviti et al., 2011). Thus, the possibility to deliver agents in a specific manner to defined target cells opens a wide avenue of research, even to overcome important challenges such as biological barriers, or tolerance to vesicles by using those derived from patient cells.

\section{CONCLUSION}

In this review we illustrate the sequential steps for exosomemediated communication and compile the evidence supporting this role in eukaryotes. Although exosomes have been described in many cells from a wide variety of organisms, many important gaps remain concerning their formation cascade and their physiological relevance. Addressing these questions implies important challenges, such as the development of sensitive techniques to purify these nanovesicles from small volumes of fluids and to determine precisely how and with what types of cells exosomes interact in vivo. The disclosure and growth of this research area will help to address these issues and lead to major advances in understanding exosomal functions as means for cell-to-cell communication.

\section{ACKNOWLEDGMENTS}

This work was supported by grants from FONDECYT no. 1110987 (FAC) and no. 3110014 (MALV) and Millenium Nucleus N ${ }^{\circ}$ P-07-011-F.

\section{REFERENCES}

ABOUNIT S, ZURZOLO C (2012) Wiring through tunneling nanotubes--from electrical signals to organelle transfer. J Cell Sci 125:1089-98.

ALBUQUERQUE PC, NAKAYASU ES, RODRIGUES ML, FRASES S, CASADEVALL A, ZANCOPE-OLIVEIRA RM, ALMEIDA IC,
NOSANCHUK JD (2008) Vesicular transport in Histoplasma capsulatum: an effective mechanism for trans-cell wall transfer of proteins and lipids in ascomycetes. Cell Microbiol 10:1695-710.

AL-NEDAWI K, MEEHAN B, MICALLEF J, LHOTAK V, MAY L, GUHA A, RAK J (2008) Intercellular transfer of the oncogenic receptor EGFRvIII by microvesicles derived from tumour cells. Nat Cell Biol 10:619-24.

ALVAREZ-ERVITI L, SEOW Y, YIN H, BETTS C, LAKHAL S, WOOD MJ (2011) Delivery of siRNA to the mouse brain by systemic injection of targeted exosomes. Nat Biotechnol 29:341-5.

AN Q, VAN BEL AJ, HUCKELHOVEN R (2007) Do plant cells secrete exosomes derived from multivesicular bodies? Plant Signal Behav 2:4-7.

BABST M (2011) MVB vesicle formation: ESCRT-dependent, ESCRTindependent and everything in between. Curr Opin Cell Biol 23:452-7.

BAIETTI MF, ZHANG Z, MORTIER E, MELCHIOR A, DEGEEST G, GEERAERTS A, IVARSSON Y, DEPOORTERE F, COOMANS C, VERMEIREN E, ZIMMERMANN P, DAVID G (2012) Syndecansyntenin-ALIX regulates the biogenesis of exosomes. Nat Cell Biol 14:677-85.

BARRETO A, RODRIGUEZ LS, ROJAS OL, WOLF M, GREENBERG HB, FRANCO MA, ANGEL J (2010) Membrane vesicles released by intestinal epithelial cells infected with rotavirus inhibit T-cell function. Viral Immunol 23:595-608.

BAYER-SANTOS E, AGUILAR-BONAVIDES C, RODRIGUES SP, CORDERO EM, MARQUES AF, VARELA-RAMIREZ A, CHOI H, YOSHIDA N, DA SILVEIRA JF, ALMEIDA IC (2012) Proteomic analysis of Trypanosoma cruzi secretome: characterization of two populations of extracellular vesicles and soluble proteins. J Proteome Res 107:9.

BECKETT K, MONIER S, PALMER L, ALEXANDRE C, GREEN H, BONNEIL E, RAPOSO G, THIBAULT P, BORGNE RL, VINCENT JP (2012) Drosophila S2 Cells Secrete Wingless on Exosome-Like Vesicles but the Wingless Gradient Forms Independently of Exosomes. Traffic (in Press).

BOBRIE A, COLOMBO M, RAPOSO G, THERY C (2011) Exosome secretion: molecular mechanisms and roles in immune responses. Traffic 12:1659-68.

EMMANOUILIDOU E, MELACHROINOU K, ROUMELIOTIS T, GARBIS SD, NTZOUNI M, MARGARITIS LH, STEFANIS L, VEKRELLIS K (2010) Cellproduced alpha-synuclein is secreted in a calcium-dependent manner by exosomes and impacts neuronal survival. J Neurosci 30:6838-51.

FAURE J, LACHENAL G, COURT M, HIRRLINGER J, CHATELLARDCAUSSE C, BLOT B, GRANGE J, SCHOEHN G, GOLDBERG Y, BOYER V, KIRCHHOFF F, RAPOSO G, GARIN J, SADOUL R (2006) Exosomes are released by cultured cortical neurones. Mol Cell Neurosci 31:642-8.

FEVRIER B, VILETTE D, ARCHER F, LOEW D, FAIGLE W, VIDAL M, LAUDE H, RAPOSO G (2004) Cells release prions in association with exosomes. Proc Natl Acad Sci U S A 101:9683-8.

FITZNER D, SCHNAARS M, VAN ROSSUM D, KRISHNAMOORTHY G, DIBAJ P, BAKHTI M, REGEN T, HANISCH UK, SIMONS M (2011) Selective transfer of exosomes from oligodendrocytes to microglia by macropinocytosis. J Cell Sci 124:447-58.

FRUHBEIS C, FROHLICH D, KRAMER-ALBERS EM (2012) Emerging roles of exosomes in neuron-glia communication. Front Physiol 3:119.

GALLO A, TANDON M, ALEVIZOS I, ILLEI GG (2012) The majority of microRNAs detectable in serum and saliva is concentrated in exosomes. PLoS One 7:e30679.

GRIMMELIKHUIJZEN CJ, HAUSER F (2012) Mini-review: the evolution of neuropeptide signaling. Regul Pept 177 Suppl:S6-9.

GROSS JC, CHAUDHARY V, BARTSCHERER K, BOUTROS M (2012) Active Wnt proteins are secreted on exosomes. Nat Cell Biol 14:1036-45.

HANSON PI, SHIM S, MERRILL SA (2009) Cell biology of the ESCRT machinery. Curr Opin Cell Biol 21:568-74.

HARDING C, HEUSER J, STAHL P (1983) Receptor-mediated endocytosis of transferrin and recycling of the transferrin receptor in rat reticulocytes. J Cell Biol 97:329-39.

HARTMAN ZC, WEI J, GLASS OK, GUO H, LEI G, YANG XY, OSADA T, HOBEIKA A, DELCAYRE A, LE PECQ JB, MORSE MA, CLAY TM, LYERLY HK (2011) Increasing vaccine potency through exosome antigen targeting. Vaccine 29:9361-7.

HSU C, MOROHASHI Y, YOSHIMURA S, MANRIQUE-HOYOS N, JUNG S, LAUTERBACH MA, BAKHTI M, GRONBORG M, MOBIUS W, RHEE J, BARR FA, SIMONS M (2010) Regulation of exosome secretion by Rab35 and its GTPase-activating proteins TBC1D10A-C. J Cell Biol 189:223-32.

HUAN J, HORNICK NI, SKINNER AM, GOLOVIZNINA NA, ROBERTS CT, KURRE P (2013) RNA trafficking by acute myeloid leukemia exosomes. Cancer Res 73:918-29.

HURLEY JH, EMR SD (2006) The ESCRT complexes: structure and mechanism of a membrane-trafficking network. Annu Rev Biophys Biomol Struct 35:277-98. 
JOHNSTONE RM, ADAM M, HAMMOND JR, ORR L, TURBIDE C (1987) Vesicle formation during reticulocyte maturation. Association of plasma membrane activities with released vesicles (exosomes). J Biol Chem 262:9412-20.

KELLER P, SIMONS K (1997) Post-Golgi biosynthetic trafficking. J Cell Sci 110 ( Pt 24):3001-9.

KHAN S, JUTZY JM, VALENZUELA MM, TURAY D, ASPE JR, ASHOK A, MIRSHAHIDI S, MERCOLA D, LILLY MB, WALL NR (2012) Plasmaderived exosomal survivin, a plausible biomarker for early detection of prostate cancer. PLoS One 7:e46737.

KOLES K, NUNNARI J, KORKUT C, BARRIA R, BREWER C, LI Y, LESZYK J, ZHANG B, BUDNIK V (2012) Mechanism of evenness interrupted (Evi)-exosome release at synaptic boutons. J Biol Chem 287:16820-34.

KORKUT C, ATAMAN B, RAMACHANDRAN P, ASHLEY J, BARRIA R, GHERBESI N, BUDNIK V (2009) Trans-synaptic transmission of vesicular Wnt signals through Evi/Wntless. Cell 139:393-404.

KRIEBEL PW, BARR VA, RERICHA EC, ZHANG G, PARENT CA (2008) Collective cell migration requires vesicular trafficking for chemoattractant delivery at the trailing edge. J Cell Biol 183:949-61.

LAKKARAJU A, RODRIGUEZ-BOULAN E (2008) Itinerant exosomes: emerging roles in cell and tissue polarity. Trends Cell Biol 18:199-209.

LASSER C, ALIKHANI VS, EKSTROM K, ELDH M, PAREDES PT, BOSSIOS A, SJOSTRAND M, GABRIELSSON S, LOTVALL J, VALADI H (2011) Human saliva, plasma and breast milk exosomes contain RNA: uptake by macrophages. J Transl Med 9:9.

LAVIALLE F, DESHAYES S, GONNET F, LARQUET E, KRUGLIK SG, BOISSET N, DANIEL R, ALFSEN A, TATISCHEFF I (2009) Nanovesicles released by Dictyostelium cells: a potential carrier for drug delivery. Int J Pharm 380:206-15.

LENASSI M, CAGNEY G, LIAO M, VAUPOTIC T, BARTHOLOMEEUSEN K CHENG Y, KROGAN NJ, PLEMENITAS A, PETERLIN BM (2010) HIV Nef is secreted in exosomes and triggers apoptosis in bystander CD4+ T cells. Traffic 11:110-22.

LEVY S, SHOHAM T (2005) The tetraspanin web modulates immunesignalling complexes. Nat Rev Immunol 5:136-48.

LI $X$, LI JJ, YANG JY, WANG DS, ZHAO W, SONG WJ, LI WM, WANG JF, HAN W, ZHANG ZC, YU Y, CAO DY, DOU KF (2012) Tolerance induction by exosomes from immature dendritic cells and rapamycin in a mouse cardiac allograft model. PLoS One 7:e44045.

LIEGEOIS S, BENEDETTO A, GARNIER JM, SCHWAB Y, LABOUESSE M (2006) The V0-ATPase mediates apical secretion of exosomes containing Hedgehog-related proteins in Caenorhabditis elegans. J Cell Biol 173:949-61.

LV LH, WAN YL, LIN Y, ZHANG W, YANG M, LI GL, LIN HM, SHANG CZ, CHEN YJ, MIN J (2012) Anticancer drugs cause release of exosomes with heat shock proteins from human hepatocellular carcinoma cells that elicit effective natural killer cell antitumor responses in vitro. J Biol Chem 287:15874-85.

MACDONALD C, BUCHKOVICH NJ, STRINGER DK, EMR SD, PIPER RC (2012) Cargo ubiquitination is essential for multivesicular body intralumenal vesicle formation. EMBO Rep 13:331-8.

MARSH M, VAN MEER G (2008) Cell biology. No ESCRTs for exosomes. Science 319:1191-2.

MATHIVANAN S, SIMPSON RJ (2009) ExoCarta: A compendium of exosomal proteins and RNA. Proteomics 9:4997-5000.

MIRANDA KC, BOND DT, MCKEE M, SKOG J, PAUNESCU TG, DA SILVA N, BROWN D, RUSSO LM (2010) Nucleic acids within urinary exosomes/microvesicles are potential biomarkers for renal disease. Kidney Int 78:191-9.

MITTELBRUNN M, GUTIERREZ-VAZQUEZ C, VILLARROYA-BELTRI C, GONZALEZ S, SANCHEZ-CABO F, GONZALEZ MA, BERNAD A, SANCHEZ-MADRID F (2011) Unidirectional transfer of microRNA-loaded exosomes from $\mathrm{T}$ cells to antigen-presenting cells. Nat Commun 2:282.

MONTECALVO A, LARREGINA AT, SHUFESKY WJ, STOLZ DB, SULLIVAN ML, KARLSSON JM, BATY CJ, GIBSON GA, ERDOS G, WANG Z, MILOSEVIC J, TKACHEVA OA, DIVITO SJ, JORDAN R, LYONS-WEILER J, WATKINS SC, MORELLI AE (2012) Mechanism of transfer of functional microRNAs between mouse dendritic cells via exosomes. Blood 119:756-66

MORELLI AE, LARREGINA AT, SHUFESKY WJ, SULLIVAN ML, STOLZ DB, PAPWORTH GD, ZAHORCHAK AF, LOGAR AJ, WANG Z, WATKINS SC, FALO LD, JR., THOMSON AW (2004) Endocytosis, intracellular sorting, and processing of exosomes by dendritic cells. Blood 104:3257-66.

NICKEL W (2005) Unconventional secretory routes: direct protein export across the plasma membrane of mammalian cells. Traffic 6:607-14.
O'LOUGHLIN AJ, WOFFINDALE CA, WOOD MJ (2012) Exosomes and the emerging field of exosome-based gene therapy. Curr Gene Ther 12:262-74.

ORELLANA JA, SANCHEZ HA, SCHALPER KA, FIGUEROA V, SAEZ JC (2012) Regulation of intercellular calcium signaling through calcium interactions with connexin-based channels. Adv Exp Med Biol 740:777-94.

OSTROWSKI M, CARMO NB, KRUMEICH S, FANGET I, RAPOSO G, SAVINA A, MOITA CF, SCHAUER K, HUME AN, FREITAS RP, GOUD B, BENAROCH P, HACOHEN N, FUKUDA M, DESNOS C, SEABRA MC, DARCHEN F, AMIGORENA S, MOITA LF, THERY C (2010) Rab27a and Rab27b control different steps of the exosome secretion pathway. Nat Cell Biol 12:19-30; sup pp 1-13.

PAN BT, TENG K, WU C, ADAM M, JOHNSTONE RM (1985) Electron microscopic evidence for externalization of the transferrin receptor in vesicular form in sheep reticulocytes. J Cell Biol 101:942-8.

PANT S, HILTON H, BURCZYNSKI ME (2012) The multifaceted exosome: biogenesis, role in normal and aberrant cellular function, and frontiers for pharmacological and biomarker opportunities. Biochem Pharmacol 83:1484-94.

PAROLINI I, FEDERICI C, RAGGI C, LUGINI L, PALLESCHI S, DE MILITO A, COSCIA C, IESSI E, LOGOZZI M, MOLINARI A, COLONE M, TATTI M, SARGIACOMO M, FAIS S (2009) Microenvironmental pH is a key factor for exosome traffic in tumor cells. J Biol Chem 284:34211-22.

PEINADO H, ALECKOVIC M, LAVOTSHKIN S, MATEI I, COSTA-SILVA B, MORENO-BUENO G, HERGUETA-REDONDO M, WILLIAMS C, GARCIA-SANTOS G, GHAJAR C, NITADORI-HOSHINO A, HOFFMAN C, BADAL K, GARCÍA BA, CALLAHAN MK, YUAN J, MARTINS VR, SKOG J, KAPLAN RN, BRADY MS, WOLCHOK JD, CHAPMAN PB, KANG Y, BROMBERG J, LYDEN D (2012) Melanoma exosomes educate bone marrow progenitor cells toward a pro-metastatic phenotype through MET. Nat Med 18:883-91.

QU Y, RAMACHANDRA L, MOHR S, FRANCHI L, HARDING CV, NUNEZ G, DUBYAK GR (2009) P2X7 receptor-stimulated secretion of MHC class II-containing exosomes requires the ASC/NLRP3 inflammasome but is independent of caspase-1. J Immunol 182:5052-62.

RANA S, ZOLLER M (2011) Exosome target cell selection and the importance of exosomal tetraspanins: a hypothesis. Biochem Soc Trans 39:559-62.

RAPOSO G, NIJMAN HW, STOORVOGEL W, LIEJENDEKKER R, HARDING CV, MELIEF CJ, GEUZE HJ (1996) B lymphocytes secrete antigen-presenting vesicles. J Exp Med 183:1161-72.

RECORD M, SUBRA C, SILVENTE-POIROT S, POIROT M (2011) Exosomes as intercellular signalosomes and pharmacological effectors. Biochem Pharmacol 81:1171-82.

REGENTE M, CORTI-MONZON G, MALDONADO AM, PINEDO M, JORRIN J, DE LA CANAL L (2009) Vesicular fractions of sunflower apoplastic fluids are associated with potential exosome marker proteins. FEBS Lett 583:3363-6.

REGENTE M, PINEDO M, ELIZALDE M, DE LA CANAL L (2012) Apoplastic exosome-like vesicles: a new way of protein secretion in plants? Plant Signal Behav 7:544-6.

RODRIGUES ML, NAKAYASU ES, OLIVEIRA DL, NIMRICHTER L, NOSANCHUK JD, ALMEIDA IC, CASADEVALL A (2008) Extracellular vesicles produced by Cryptococcus neoformans contain protein components associated with virulence. Eukaryot Cell 7:58-67.

RODRIGUES ML, NOSANCHUK JD, SCHRANK A, VAINSTEIN MH, CASADEVALL A, NIMRICHTER L (2011) Vesicular transport systems in fungi. Future Microbiol 6:1371-81.

ROUNTREE RB, MANDL SJ, NACHTWEY JM, DALPOZZO K, DO L, LOMBARDO JR, SCHOONMAKER PL, BRINKMANN K, DIRMEIER U, LAUS R, DELCAYRE A (2011) Exosome targeting of tumor antigens expressed by cancer vaccines can improve antigen immunogenicity and therapeutic efficacy. Cancer Res 71:5235-44.

SAMAN S, KIM W, RAYA M, VISNICK Y, MIRO S, JACKSON B, MCKEE AC, ALVAREZ VE, LEE NC, HALL GF (2012) Exosome-associated tau is secreted in tauopathy models and is selectively phosphorylated in cerebrospinal fluid in early Alzheimer disease. J Biol Chem 287:3842-9.

SAUNDERSON SC, SCHUBERTH PC, DUNN AC, MILLER L, HOCK BD, MACKAY PA, KOCH N, JACK RW, MCLELLAN AD (2008) Induction of exosome release in primary B cells stimulated via CD40 and the IL-4 receptor. J Immunol 180:8146-52.

SAVINA A, FADER CM, DAMIANI MT, COLOMBO MI (2005) Rab11 promotes docking and fusion of multivesicular bodies in a calciumdependent manner. Traffic 6:131-43.

SAVINA A, FURLAN M, VIDAL M, COLOMBO MI (2003) Exosome release is regulated by a calcium-dependent mechanism in K562 cells. J Biol Chem 278:20083-90. 
SILVERMAN JM, CLOS J, DE'OLIVEIRA CC, SHIRVANI O, FANG Y, WANG C, FOSTER LJ, REINER NE (2010) An exosome-based secretion pathway is responsible for protein export from Leishmania and communication with macrophages. J Cell Sci 123:842-52.

SIMONS M, RAPOSO G (2009) Exosomes--vesicular carriers for intercellular communication. Curr Opin Cell Biol 21:575-81.

SKOG J, WURDINGER T, VAN RIJN S, MEIJER DH, GAINCHE L, SENAESTEVES M, CURRY WT, JR., CARTER BS, KRICHEVSKY AM, BREAKEFIELD XO (2008) Glioblastoma microvesicles transport RNA and proteins that promote tumour growth and provide diagnostic biomarkers. Nat Cell Biol 10:1470-6.

SUBRA C, GRAND D, LAULAGNIER K, STELLA A, LAMBEAU G, PAILLASSE M, DE MEDINA P, MONSARRAT B, PERRET B, SILVENTEPOIROT S, POIROT M, RECORD M (2010) Exosomes account for vesicle-mediated transcellular transport of activatable phospholipases and prostaglandins. J Lipid Res 51:2105-20.

TAURO BJ, GREENING DW, MATHIAS RA, MATHIVANAN S, JI H, SIMPSON RJ (2013) Two distinct populations of exosomes are released from LIM1863 colon carcinoma cell-derived organoids. Mol Cell Proteomics 12:587-98

THERY C, OSTROWSKI M, SEGURA E (2009) Membrane vesicles as conveyors of immune responses. Nat Rev Immunol 9:581-93.

TRAJKOVIC K, HSU C, CHIANTIA S, RAJENDRAN L, WENZEL D, WIELAND F, SCHWILLE P, BRUGGER B, SIMONS M (2008) Ceramide triggers budding of exosome vesicles into multivesicular endosomes. Science 319:1244-7.

VALADI H, EKSTROM K, BOSSIOS A, SJOSTRAND M, LEE JJ, LOTVALL JO (2007) Exosome-mediated transfer of mRNAs and microRNAs is a novel mechanism of genetic exchange between cells. Nat Cell Biol 9:654-9.
VANLANDINGHAM PA, CERESA BP (2009) Rab7 regulates late endocytic trafficking downstream of multivesicular body biogenesis and cargo sequestration. J Biol Chem 284:12110-24.

VELLA LJ, GREENWOOD DL, CAPPAI R, SCHEERLINCK JP, HILL AF (2008) Enrichment of prion protein in exosomes derived from ovine cerebral spinal fluid. Vet Immunol Immunopathol 124:385-93.

VIAUD S, PLOIX S, LAPIERRE V, THERY C, COMMERE PH, TRAMALLONI D, GORRICHON K, VIRAULT-ROCROY P, TURSZ T, LANTZ O, ZITVOGEL L, CHAPUT N (2011) Updated technology to produce highly immunogenic dendritic cell-derived exosomes of clinical grade: a critical role of interferon-gamma. J Immunother 34:65-75.

WHITE IJ, BAILEY LM, AGHAKHANI MR, MOSS SE, FUTTER CE (2006) EGF stimulates annexin 1-dependent inward vesiculation in a multivesicular endosome subpopulation. Embo J 25:1-12.

YANG C, CHALASANI G, NG YH, ROBBINS PD (2012) Exosomes released from Mycoplasma infected tumor cells activate inhibitory B cells. PLoS One $7: \mathrm{e} 36138$

ZERIAL M, MCBRIDE H (2001) Rab proteins as membrane organizers. Nat Rev Mol Cell Biol 2:107-17.

ZHANG H, XIE Y, LI W, CHIBBAR R, XIONG S, XIANG J (2011) CD4(+) T cell-released exosomes inhibit CD8(+) cytotoxic T-lymphocyte responses and antitumor immunity. Cell Mol Immunol 8:23-30.

ZHUANG X, XIANG X, GRIZZLE W, SUN D, ZHANG S, AXTELL RC, JU S, MU J, ZHANG L, STEINMAN L, MILLER D, ZHANG HG (2011) Treatment of brain inflammatory diseases by delivering exosome encapsulated anti-inflammatory drugs from the nasal region to the brain. Mol Ther 19:1769-79. 
